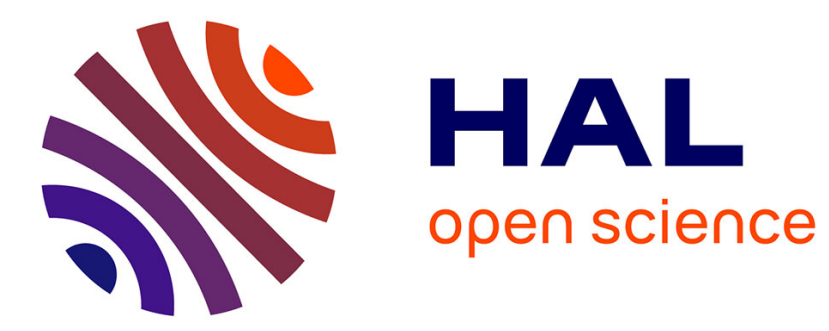

\title{
Subversion of Language Structure in Heterogeneous Speech Communities: the Work of Discourse and the Part of Contact
}

\author{
Katja Ploog
}

\section{- To cite this version:}

Katja Ploog. Subversion of Language Structure in Heterogeneous Speech Communities: the Work of Discourse and the Part of Contact. Journal of Language Contact, 2008, 2, pp.249 - 273. $10.1163 / 000000008792525200$. halshs-01385569

\section{HAL Id: halshs-01385569 \\ https://shs.hal.science/halshs-01385569}

Submitted on 21 Oct 2016

HAL is a multi-disciplinary open access archive for the deposit and dissemination of scientific research documents, whether they are published or not. The documents may come from teaching and research institutions in France or abroad, or from public or private research centers.
L'archive ouverte pluridisciplinaire HAL, est destinée au dépôt et à la diffusion de documents scientifiques de niveau recherche, publiés ou non, émanant des établissements d'enseignement et de recherche français ou étrangers, des laboratoires publics ou privés. 
à paraître in : Journal of Language Contact, Thema series $\mathrm{n}^{\circ} 2$ : Language Contact and the

Dynamics of Language : Theory and Implications, 249-273.

\title{
SUBVERSION OF LANGUAGE STRUCTURE IN HETEROGENEOUS SPEECH COMMUNITIES: THE WORK OF DISCOURSE AND THE PART OF CONTACT
}

\author{
Katja PLOOG \\ Université de Franche-Comté à Besançon
}

\section{Introduction: language dynamics}

For a long time (and in some way it is still the case) the scholastic tradition considered language change as an ungraceful deformation of the existing patterns. Indeed, change represented the danger of compromising the social order established by the standard norm; that is what Manessy (1989) expressed by the term of "subversion" in one of his articles about French in Africa. In another way, contact and interference phenomena still imply 'subversion' in Weinreich's point of view, as far as bilingual proficiency is the ability to keep the two languages apart (Weinreich 1953:3).

The underlying assumption is the structuralist dogma that human languages are stable sets of units and combination rules. Contact involves subversion in the sense that the encounter with an alien system leaves traces in the language under consideration. Essentially, the problem is to prove what seems to be an evident observation: as languages do not exist by themselves, they cannot be in contact. Only speakers and speech communities are effectively in contact, by interacting in concrete situations. If the so-called 'language contact' takes place in interactions, it would be impossible to observe language contact directly, and the concept could even less explain directly what is going on.

The aim of our contribution is to render the assumption explicit that change is an ongoing process constitutive of human language to which we will refer by the term of dynamics. We will discuss how the general tendency of grammatical 'systems' to autonomize by promoting their own, 'self-contained' (Croft 1995) logic is counter-balanced through the subversion that occurs in everyday's elaboration of discourse. We will work out how mere interaction conditions the language dynamics and how the disposable structural resources will be coordinated in microsystems that can be traced back to different typological sources. Our purpose will be illustrated by an example from the contact between French and Manding languages in Ivory Coast.

\footnotetext{
${ }^{1}$ The author would like to thank Gérard Dumestre, Françoise Gadet, Sewoenam Gbordzi, Robert Nicolaï, Klaus Ploog and Natalie Webb for their critical reading of the preliminar versions.
} 
à paraître in : Journal of Language Contact, Thema series $\mathrm{n}^{\circ} 2$ : Language Contact and the Dynamics of Language : Theory and Implications, 249-273.

\section{Framework}

\subsection{The work of discourse: historicity}

Oesterreicher (2003) argues that linguistic historicity is much more than the effect of observed changes: Since historicity results directly from cognition, it has to be counted among the essential universals of natural language. Referring to the five universal characteristics of speaking outlined by Coseriu (1981) - exteriority, semanticity, alterity, creativeness, discursivity-he delimits historicity as the product of alterity and creativeness. Oesterreicher (2003:48-9) considers variation as the internal aspect of historicity and interlinguistic divergence as the external one: If variation derives from applying discursive techniques bound to the pragmatic demands of discourse, interlinguistic divergence is the result of historical modification of functional rules and norms.

\subsection{Subversion of language structure: emergent grammar}

Hopper's concept of emergent grammar offers a dynamic model for describing language structure by precising what is called the discursivity aspect of language as stated above: If discourse forms undergo structural reinterpretation, they are only potentially perceived as norms:

The notion of Emergent Grammar is meant to suggest that structure, or regularity, comes out of discourse and is shaped by discourse as much as it shapes discourse in an on-going process. Grammar is hence not to be understood as a pre-requisite for discourse, a prior possession attributable in identical form to both speaker and hearer. Its forms are not fixed templates but are negotiable in face-to-face interaction in ways that reflect the individual speakers' past experience of these forms, and their assessment of the present context, including especially their interlocutors, whose experiences and assessments may be quite different. Moreover, the term Emergent Grammar points to a grammar which is not abstractly formulated and abstractly represented, but always anchored in the specific concrete form of an utterance. (Hopper 1987:142)

Hopper (1987:146) outlines three principles in describing the doctrine of emergent structure:

a) There is no qualitative difference between discursive traditions and other structural rules, because "no principled line can be drawn between the emergent regularities designated to be 'grammatical' and other regularities deemed to be 'rhetorical', 'formulaic', etc." Contrary to Oesterreicher's claim, Hopper considers linguistic norms as a certain type of discursive tradition.

b) As it is "anchored in the specific concrete form of an utterance", grammar is dynamic in the sense that "there is [...] no 'grammar' but only 'grammaticization'- movements toward structure which are often characterizable in typical ways." This is what Oesterreicher would call historicity. The method recommended by Hopper consists in a distributional approach in order to identify structure regularities, that will be called constructions here.

c) In order to discover the mechanisms and processes of 'grammaticization', "the major descriptive project of Emergent Grammar is to identify recurrent strategies for building discourses":

It is a question of possessing a repertoire of strategies for building discourses and reaching into memory in order to improvise and assemble them. Grammar is now not to be seen as the only, or even the major, source of regularity, but instead grammar is what results when formulas are rearranged, or dismantled and re-assembled, in different ways. (Hopper 1987:144)

A major postulate, or working hypothesis, of Emergent Grammar is that the more useful a construction is, the more it will tend to become structuralized, in the sense of achieving crosstextual consistency, and serving as a basis for variation and extension. (Hopper 1987:147) 
à paraître in : Journal of Language Contact, Thema series $\mathrm{n}^{\circ} 2$ : Language Contact and the Dynamics of Language : Theory and Implications, 249-273.

It remains to establish what can be a useful construction, and more specifically in a contact situation.

\subsection{The part of contact in language dynamics}

The current investigation into 'language contact' focusses on various aspects of the phenomenon: Myers-Scotton (2002) describes the domain of contact linguistics as being the study of bilingual speakers' grammar. On the contrary, Heine \& Kuteva (2005) claim that, despite the fact that it is not a discipline of its own, contact linguistics has to prioritize linguistic activity and its products over cognitive issues.

The product of linguistic dynamics seems to show a modification of the mere functional patterns by a grammaticalization (Lehmann 1995) or a reanalysis (Langacker 1977) process, supposed to emerge from the proper conditions of discourse activity. But in many cases, it has to be asked to what extent the ongoing change is influenced by the underlying contact situation; this hypothesis has been worked out by terms such as replication (Heine \& Kuteva 2005) or structural copying (Johanson 2005). This point of view is close to what has been described by Mithun (2007:164) as a "gradual typological alignment" of languages in a contact situation: Similar to Heine \& Kuteva (2005) or Johanson (2005), Mithun argues that, what is transferred from one language to another are more abstract distinctions that are frequently used in existing constructions, rather than the constructions as a whole. Furthermore, the diffusion can be supposed to take place in several different ways following the concrete contact constellation.

Observing French Creole languages and linguistic dynamics in Western Africa, Manessy (1989) states that a significant part of restructuring phenomena cannot be traced back either to interference or to imperfect second language learning. He proposes the concept of semantaxe (1987) for describing the influence of semantic categorizations rather than of syntagmatical features on restructurating dynamics of linguistic systems. Semantactic patterns such as aspectual oppositions in verbal morphology or prepositional structures derived from human body parts could be qualified as 'anthropolinguistic', in the sense that they reveal the semiotization of cultural experience.

Following Thomason (2001), we would call a contact-induced change a language change that is more likely to occur within a contact situation rather than without it, even if the dynamics are not contact-specific. She distinguishes two basic sociolinguistic types of contact-induced changes following whether or not imperfect learning (i.e. of a second language) plays a role. These two types seem to correlate with their linguistic 'product' (in summary, more borrowing or more structural interference). Winford (2003) also states that most contact situations can be classified by their outcome, that is to say, the maintenance or the shift of some of the languages concerned, or the creation of a new code.

These different approaches to language contact lead us to distinguish two different stages of the description of linguistic dynamics: Firstly, the elaboration of social discourse takes place by the actualization of specific mechanisms (Thomason 2001); furthermore, if there is any observable product, this is the base for the hearer's interpretation task and for the observer's analysis. Secondly, a semiotization process develops as a result of the interpretation task; this 'purely structural' stage of linguistic dynamics has to be postponed to a further study. But, if grammar exists as a process, it will be of interest to work out by what type of mechanisms a bilingual speaker elaborates his/her discourse; if the social context of contact regulates the product, this is an essential (and the most accessible) set of facts to delineate the vectors of the dynamics. 
à paraître in : Journal of Language Contact, Thema series $\mathrm{n}^{\circ} 2$ : Language Contact and the Dynamics of Language : Theory and Implications, 249-273.

\subsection{Hypothesis: language dynamics}

We will argue that language dynamics refers to the everyday process that develops in a speech community, delimited by a set of relevant discursive configurations and by underlying historic social constellations.

The qualitative assumption is that the more heterogeneous the speech community is, the more dynamic its communication modes will be. Referring to principle 3 (Hopper 1987, see above), we will discuss what can be called a (more) 'useful' construction and through what type of mechanisms the constructions do compete ${ }^{2}$ or get coordinated, specifically in contexts of language contact.

The quantitative assumption of this hypothesis is that the generalization of individual speech behavior leads to the stabilization of new discursive traditions (grammaticization). Referring to Hopper's principle 2, we will work out the types of processes in which the grammaticization takes place.

\section{The case of Ivory Coast}

The linguistic dynamics of Ivory Coast has developed in less than a century from a highly multilingual situation to dominance of French, at least in the urban milieu. The initial multilinguism of the country counts about 70 ethnic languages, all belonging to the Niger-Congo group (Greenberg 1963b); the principal subfamilies represented are Kwa, Kru, Gur and Mande ${ }^{3}$. At the same time, the French language has undergone heavy restructuring processes on all levels of structuring, from phonology via the lexicon to morphosyntax. Before presenting one of the restructured microsystems, we will briefly outline the major phases of the development of the capital Abidjan in order to establish the factors of the social constellations likely to have influenced language dynamics, namely of Abidjanese French (nowadays called 'Nouchi').

a) The installation of the colonial governorship (1893-1933) was marked by rare contacts between French and indigenous languages from the Kwa family in the coastal area. The first missionary schools opened and initialized the francization process. Thus, the use of the French language was at the time ultra-minoritary and restricted to both vehicular and prestigious functions.

b) At the beginning of the first urban expansion period (1933-1951), the headquarters were transferred to the Abidjan location. The development of the urban nucleus involved the first immigration waves and led to the intensification and diversification of language contacts (approximately 30 ethnic groups, mostly from the Kwa and Manding families). The use of French increased consistently during the structuring process of the colonial power; but although the acquisition of French as a second language developed, Dyula still remained the traditional urban commercial language that it has been since the Middle Ages. During this phase of individual multilateral multilinguism, communicative (palliative) code-switching and situational code alternation may have been characteristic of the community's speech mode.

c) The Ivorian miracle describes the period following the opening of the international port (1951-1975) ${ }^{4}$. While more and more immigrants from the surrounding countries flowed towards Abidjan and while the urbanization process was left to the very population ${ }^{5}$,

\footnotetext{
2 The term of 'competing grammars' has been forged by Kroch $(1989,2001)$, although within different framework.

${ }^{3}$ Additionally, we have to mention from 20 to 30 immigrant languages, most of them belonging to the same families.

${ }^{4}$ Independence 1960.

${ }^{5}$ The annual growth of the city reaches $16 \%$ in the early sixties.
} 
à paraître in : Journal of Language Contact, Thema series $\mathrm{n}^{\circ} 2$ : Language Contact and the

Dynamics of Language : Theory and Implications, 249-273.

French became the main common language. Within a context of heavy social competition, the old colonial language might have been considered to offer better social upward mobility than Dyula, which is associated with informal trading and Muslim culture. The constant renewal of the population and the low education level of the immigrants induced, in this phase, the strongest dynamicity of the French language, and led to the (relative) stabilization of new norms that have been called 'Popular Abidjanese French' (FPA) in linguistic literature. We assume that the higher heterogeneity of the community and its better competence in urban interaction, concentrate communicative (palliative) codeswitching in Dyula/French and code alternation in indigenous/French contact.

Unfortunately, there is very little information available about speech behavior, and even fewer corpora from these two phases ${ }^{6}$.

d) Follows the Ivorian mirage (1975-1985): The decline of coffee and cocoa prices initiated a (still lasting) recessionary period. The schooling policy did not progress and the population became disenchanted with the economic model. During this phase, the adaptation-integration mechanism faced a second, segregationist one: The losers of the urban competition began to mark their identity by the creation of specific discursive modes drawn from the common local resources (whose dominant part was from then on constituted by FPA). This dynamics led to the constitution of Nouchi ${ }^{7}$, promoting identitary code-switching in the domains relevant to argot; as a parallel process, communicative code-switching vanished.

e) The decrease of immigration in the later eighties contributed to the stabilization of ivority $^{8}$ (1985-1997): The linguistic behavior branched out whilst still remaining focussed on (some) French. FPA was transmitted to the second generation and underwent structural change; Nouchi became appropriated by emergent local artistic currents and was adopted by wider population groups. The diffusion of standard French stagnated. In this highly diglossic situation, we can suppose that the performances reflect the characteristics of the speaker's appropriation of French. The fact that the awareness of socioindexicality of language use was then highly structured brought about more individual discursive mobility, in order to fit with the interaction, as far as the speaker's repertory permitted. Several local heterogeneities have been observed that reflect discrepancies between social and linguistic competence.

f) Up to now, ivority has been consolidating around Nouchi $(<1997)$. The term now designates the local linguistic identity, including non-marked daily use of spoken, nonstandard French. Native urbans grow up with Nouchi-French and the only residue of multilinguism is in most cases a passive familiarity with one of the original ethnic languages and/or with Dyula.

In summary, we observe that the linguistic dynamics run from individual multilinguism to the generalization of French in a context of decreasing familiarity with Dyula. The social dynamics of the constitution of the speech community through violent urban growth (including competition and destabilization of traditional orders) was marked by widespread (heterogeneous) human components. The most dynamic periods are the maximal contact phase (3) when French became the

\footnotetext{
${ }^{6}$ The most precise information proceeds from Hattiger 1983.

${ }^{7}$ At first, the term applies the social group of juvenile delinquents before the communication mode. Several etymologies have been proposed; it seems to derive from nou-chi 'hair of nose' in Susu, a Mande language from Guinea.

${ }^{8}$ Ivoirité was the central keyword of Houphouêt-Boigny's politics against latent ethnic divergencies.
} 
à paraître in : Journal of Language Contact, Thema series $\mathrm{n}^{\circ} 2$ : Language Contact and the Dynamics of Language : Theory and Implications, 249-273.

common language, and the phase of subcategorization of the different uses of French (5). In the following pages, we present one of the very characteristic phenomena of linguistic dynamics, before outlining the strategies supposed to motivate the observed restructuring.

\section{Theoretical assumptions}

\subsection{Pragmatic demands}

Thomason (2001) discusses seven discourse mechanisms that are supposed to induce language change in contact situations. In Ploog (2008, forthcoming), we argue that none of the entries of this eclectic set of mechanisms ${ }^{9}$ seem to be contact-specific as they merely derive from general characteristics of the discursive situation. More generally, we would assume that all discursive mechanisms are bound to satisfy the pragmatic demands of an actual speech production. But, as pointed out by Jacob (2003:66ff.), there are heavy theoretical divergences about what should be called a 'pragmatic' factor: with reference to Hopper (1979), pragmatic demands determine discursive elaboration of referential entities as a textual factor; as a psychological factor, they also describe the individual involvement of the speaker in discursive elaboration (Fleischmann 1983); since innovation in discursive elaboration takes place by metaphorical and metonymical strategies, pragmatic demands can be seen as an implicational factor (according to Grice and Traugott \& König 1991); finally, the dual aspect of interpretation (and further elaboration) of linguistic structures in the semiotization process that leads from more propositional to more textual meanings or from an external (more objective) situation to an internal (more subjective) one of discourse elaboration constitutes a metalinguistic factor (Traugott \& König 1991:208f. and Langacker 1990:16). In another perspective, pragmatic demands can be traced back to Grice's (1975) cooperative principle ${ }^{10}$ and the resulting conversational maxims (quantity, quality, relation and manner).

Though Jacob (2003) details these factors within a discussion around grammaticalization, we would assume that they have to be considered as non specific in the sense that they derive from the universal aspects of speech outlined by Coseriu (1981, see above) and that they possibly influence any change of linguistic behavior. Thus, we would claim that they all contribute to the definition of the pragmatic meaning of a linguistic structure. Keeping our purpose in view, we will retain the following three basic pragmatic demands supposed to be satisfied by any elaboration of discourse:

a) Referentiality describes the semiotization process that involves semanticity, exteriority and creativeness. It determines the mechanisms of cohesion and coherence like phoric strategies or temporal actualization.

b) Interlocutivity means alterity, exteriority and creativeness. It describes all at once the pragmatic intentionality (alterity) of discourse, and the duality of articulation and perception (exteriority) that involves structuring discrepancies. Creativeness has to be understood in the sense that socioindexicality of language can stimulate the speaker to innovate linguistic features, in order to negotiate faces in the sense of Goffman (1959, 1963).

c) Linearity of spoken language results from exteriority (running time) and discursivity (scheduling referential hierarchies) and involves all the phenomena related to sequencing and segmentation of the formal chain (word order, hesitation, etc).

We will argue that the most useful items are those which best satisfy the pragmatic demands. If

\footnotetext{
9 I.e. Code-switching, code alternation, passive familiarity, 'negotiation', second-language acquisition strategies, bilingual first-language acquisition and change by deliberate decision (Thomason 2001:129ff.).

10 "Make your conversational contribution such as is required, at the stage at which it occurs, by the accepted purpose or direction of the talk exchange in which you are engaged."
} 
à paraître in : Journal of Language Contact, Thema series $\mathrm{n}^{\circ} 2$ : Language Contact and the Dynamics of Language : Theory and Implications, 249-273.

similar discursive configurations lead to the actualization of similar mechanisms, the first step to understanding the dynamics is to describe the functional features of the observable with respect to its pragmatic demands.

\subsection{Microsystems}

A set of related formal and functional features will be referred to here as a microsystem. In many cases, the traditional concept of the paradigm is sufficient to describe the formal oppositions that occur in a given syntactical (or discursive) position; but the oppositions can compose a merely functional 'paradigm'; furthermore, the - not less traditional-linguistic variation makes us observe competitions between oppositions or even entire paradigms. These oppositions and competitions can be supposed to be structured in the speakers' competence, that is what we would call a system.

Different microsystems have to be coordinated in order to permit the global elaboration of coherent and cohesive discourse. The concept of a micro-system is justified by our intention to show structural mechanisms of heterogeneity in a restricted part of a global repertory of elaboration strategies (the 'macro-system', if there is such a thing). The following section will discuss the features of the microsystem of LA in Abidjanese speech. We assume that today's microsystem is set up from resources from different historic language entities, in other words, the dynamics consists of the integration of at least two microsystems into one.

\subsection{Description categories}

The demand of reliable description categories goes hand in hand with the quality of the following analysis, and, even more so, the comparison of constructions from different historic traditions. Thus we intend to use the most general labels in order to avoid anticipation of structural interpretation and misunderstandings resulting from the divergence of grammatical traditions.

We will basically distinguish three types of linguistic units, following their form and function in discourse structuring:

- Constituents are full syntactical units, phonological heavy and dominant in phrase hierarchies.

- Markers are discursive ('macrosyntactical' in the sense of Blanche-Benveniste 1987) units that are formally weaker than constituents (tend to produce phonological variation/reduction), but independent from morpho-syntactical hierarchies as they apply to different constituent types.

- Formers are semantic or pragmatic units from the morphological level that ensure the microand macrosyntactical functioning of the constituents.

The notorious diversity of use of the item LA leads us to start at the pure inventory of its morphological paradigms.

\section{Microsystems in Contact: LA in Dyula and French}

\subsection{LA in French}

We suppose the reader to be familiar with the more general characteristics of standard French as an analytic, flexional Indo-European language.

\subsubsection{Morphological paradigms}

French possesses two morphological paradigms for LA, the second one historically derives from the first:

- one constituent, which is a secondary verbal argument with locative meaning that will be preposed or postponed to the verbal structure, following its syntactical function: 
à paraître in : Journal of Language Contact, Thema series $\mathrm{n}^{\circ} 2$ : Language Contact and the Dynamics of Language : Theory and Implications, 249-273.

(1) attends + regarde je mets le filet ++ regarde + il est là

(DGLF BOR99, P17:H.3.92)

(2) euh là il est trois heures et demie

(DGLF BOR99, E36:E08.31)

- one postnominal discontinued demonstrative marker:

(3) et pourquoi ça a ces couleurs-là

(DGLF BOR99, E40:H.3.11)

(4) celui-là il te serre

(DGLF BOR99, P07:E7.55)

Both of these paradigms have undergone specific modifications in Abidjanese use. The more detailed characteristics of these paradigms in Abidjanese French that feature in annex 1 have been described in our earlier works (Ploog 2002, 2006, Knutsen \& Ploog 2005).

\subsubsection{The restructuring of LA: from standard to Abidjanese French}

The use of LA is characterized by the coexistence of the two paradigms in different microsystems, but each of them has undergone functional modifications. The most surprising of them may be what can be called a recategorization of the constituent (Ploog 2002), in constructions where LA seems to furnish the only syntactic argument of the predication (i.e. the 'subject' of the clause):

(5) laczon

LOC-être+SG+PRES-jaune ${ }^{11}$

là (c')est jaune / là, il y a du jaune (Ploog ABJ97, C11Y:VI.04.12)

As already outlined in Knutsen \& Ploog (2005), we can distinguish three phases of restructuring the clitic LA in Abidjanese French with regard to the specific determination complex:

a) Conforming to standard French, determination is prenominal; the demonstrative is expressed by the discontinued 'article' (ce N-là).

b) In FPA (phase 3 of the local dynamics) zero-marking is opposed to the postposed LA following the feature of definiteness ( $N$-ø /N-là; see Hattiger 1983).

c) The postposed LA is used complementarily to the preposed determination paradigm and tends to mark syntactic constituents other than nouns.

\footnotetext{
${ }^{11}$ ABST: abstract; ACC: accomplished; AGT: agent, CAUS: causative; COP: copula; DEF: definite; FEM: feminum; IMP: imperative; INACC: inaccomplished; LOC: locative; NEG: negation; OBJ: object; PARF: perfect; PL: plural; POSS: possessive; POST: 'postposition'; PRES: présent; PROG: progressive; SG: singular; SJ: subject; SPEC: specific. A slash in the morphological transposition notifies the ending/beginning of a graphic entity (i.e. a 'word').
} 
à paraître in : Journal of Language Contact, Thema series $\mathrm{n}^{\circ} 2$ : Language Contact and the Dynamics of Language : Theory and Implications, 249-273.

All three phases of development coexist in use nowadays.

The dynamics of LA is very well-known in a wide range of varieties deriving from French - an overview of the abundant studies can be found in Wiesmath (2003). Schøsler (2001) argues that the loss of definiteness of the preposed determiner involves a reanalysis of the postposed LA to mark definiteness in spoken French; Ludwig \& Pfänder (2003) outline the function of LA in Caribbean creoles, where it is a relative marker; In addition, as in most French Creole languages, LA tends to furnish the definite article ( $c f$. Baker 2003, Fournier 1998, Lefèbvre 1982, Lumsden 1991). Vincent (1993) assumes that it has become a phonological support to discourse segmentation in Canadian use. Wiesmath (2003) claims the coexistence in Acadian French of three development phases with more, or less deictic character (adverb, discourse marker, segmentation).

These studies show that different dynamics are highly convergent - the majority of them also exist in Abidjanese use-even if the specific morphosyntactic status of LA (for instance, \pm [obligatory]) seems to vary a lot. All authors emphasize that there are several distinct functions of LA, continuity between these functions - and that (consequently) there are a lot of occurrences where it is difficult to recognize the morphosyntactical scope of LA. We can deduce from this that structural ambiguity is a condition for language dynamics.

\subsection{LA in Manding}

\subsubsection{General features of the languages in contact}

Almost all languages which are in contact with French in Ivory Coast belong to the Niger-Congo group. Niger-Congo languages are typically tonal languages; generally these languages would prefix noun classes and suffix verbal extensions. Two of the families, Kru and Gur, suffix noun classes and verbal extensions; there seems to be some discussion about word order (SVO or $\mathrm{SMOV}^{12}$ ). Kwa languages use serialization of verbs and the dominant word order seems to be SOV. We assume that these languages are not sufficiently dominant to affect French structures on the level of the speech community.

On the contrary, languages from the Mande group might have been very influential in the local language dynamics observed in French. The most common ones in Ivory Coast (Manding: Dyula and Malinke, Yakuba, Guro) are tonal languages, with SOV word order. Conformely to Greenberg's implicational universals (Greenberg 1963a), these languages exhibit postpositions, for oblique object marking and/or post-subject TAM formatives. They appeal to suffixation for flexional values - time, number, mode (V) and definite, demonstrative, plural (N) - additionally to a wide range of derivational suffixes. Manding languages (i.e. Dyula, Malinke) do not distinguish either noun classes or grammatical gender.

\subsubsection{Morphologic paradigms}

In the Manding languages, the form LA fulfills a large variety of functions. As there is no reliable general description for this group, and more specifically no information detailing the closeness between the different linguistic entities in Ivory Coast, we have to combine sources from different authors and (what is more problematic) from different geographic areas. But since Manding is described as a relatively homogeneous subfamily (Bendor-Samuel 1989:50) and since all of these languages are present in Abidjan, we can argue by using data from several (different) languages from the Manding family ${ }^{13}$. The insufficiency of the data remains, of course, problematic,

\footnotetext{
${ }^{12} \mathrm{~S}$ : subject, $\mathrm{M}$ : tense/aspect/mode marking; O: object, V: lexical verb.

13 See References for complete references of the examples presented here; Dumestre discusses data from Bambara and Dyula (Mali, Ivory Coast), Creissels from Bambara (Mali), Mandekan (Senegal, GuineaBissau), Tröbs and Camara from Malinka (Guinea). Note that the presentation of the examples follows in general the conventions of these authors. Some standardizations have been made by the contributor (KP): The
} 
à paraître in : Journal of Language Contact, Thema series $\mathrm{n}^{\circ} 2$ : Language Contact and the Dynamics of Language : Theory and Implications, 249-273.

as does the lack of a clear overview of the functional correspondences from one linguistic entity to another.

Morphologically, four functionings can be distinguished:

- The etymon of LA seems to be a noun: Tröbs (1999:367) points out that in Jeli (CentralMande branch) there is a lexeme là $\eta$ 'place' that can be supposed to have been grammaticalized as a postposition; Although lày is not attested in Bambara/Dyula, Dumestre $^{14}$ notices its possible correspondence to $d a$ in contemporary Bambara for 'day, place' (and the phonetic correlation between [1/d]). Furthermore, the categorical difference between adverbial and nominal constituents in Manding seems to be very different from Indo-European.

- LA as a postposition, with a marker status in our terminology:

(6) tìno be mùsoo la

contraction / INACC / femme / LOC*

la femme ressent les contractions; litt. les contractions sont dans la femme (Creissels1983:165)

(7) sékù jé ádámá sơ wárí lá

Sekou / ACC / Adama / gratifier / argent / OOB*

Sekou a gratifié Adama d'une somme d'argent (Creissels 1991:366)

- LA as a derivational morpheme, with a former status:

kè-lá

mari - LOC

domicile conjugal (Creissels 1991:115)

(9) sinògò-lá

dormir - AGT*

dormeur (Creissels 1991:115)

- The status of the LA suffix in the discontinued verbal marking is not clear: in some of the literature it is treated as an affix, while Creissels (1983) interprets it as a postposition, i.e. a more independent marker:

occurrence of the observable has been emphasized and he asterisk $(*)$ notifies that the morphological segmentation is (at least partially) ours.

${ }^{14}$ Personal communication (april 2008). 
à paraître in : Journal of Language Contact, Thema series $\mathrm{n}^{\circ} 2$ : Language Contact and the Dynamics of Language : Theory and Implications, 249-273.

(10) à bòli-la

lui / courir / ACC

il a couru (Dumestre1971:52)

(11) n nye kuma-la

$1 \mathrm{SG} / \mathrm{PROG} /$ parler / PROG*

je parle (Camara 1999:37)

- $\quad$ The causative preposed verbal formative is also considered as an affix (former):

(12) lá-wuli

CAUS - lever*

soulever (cf. wúli, se lever; Dumestre 1971:55)

(13) à bé č̌ lá-bjó

lui / INACC / homme / CAUS / sortir

il fait sortir l'homme (Creissels 1991:17)

\section{Pragmatic demands and the use of LA}

The reader may already have noticed that the variety of functions of LA in Manding is confusing. Furthermore, some of the acceptions exhibit phonological variation; for instance, since the locative postposition has the same allomorphs as the causative verb formative ( $\mathrm{r}, \mathrm{n}, \mathrm{J}, 1 \mathrm{~J})$, both are supposed to have the same origin ${ }^{15}$. There seems to be no doubt that LA is undergoing a grammaticalization process in contemporary Manding so that there can be established various relationships between markers and formers. But on the other hand, are we obliged to deny diachronic relation if the items have not the same phonological variants?

Since it remains problematic to determine which of the items are related to one another without evidence from empiric data, we will treat the LA items separately, observing the merely functional closeness.

\subsection{Referentiality}

The basic reference of LA in the considered entities, French and Manding, is the expression of a wide range of locative meanings [LOC]:

(14) à béfi' ḱ dàga lá

lui / INACC / eau / mettre / marmite / LOC*

il met l'eau dans la marmite (Creissels 1991:17)

(15) a j’á búlù là

cela / être / lui / bras / à

\footnotetext{
${ }^{15}$ Source: Dumestre, personal communication (april 2008).
} 
à paraître in : Journal of Language Contact, Thema series $\mathrm{n}^{\circ} 2$ : Language Contact and the Dynamics of Language : Theory and Implications, 249-273.

il l'a au bras (Creissels 1991:114)

(16) tìno be mùsoo la (cf. 6)

The item is classified as a postposition in Manding: 'lie on' or 'with' (Camara 1999:32). The same postposition will be used for non inherent possessive genitives [GEN]:

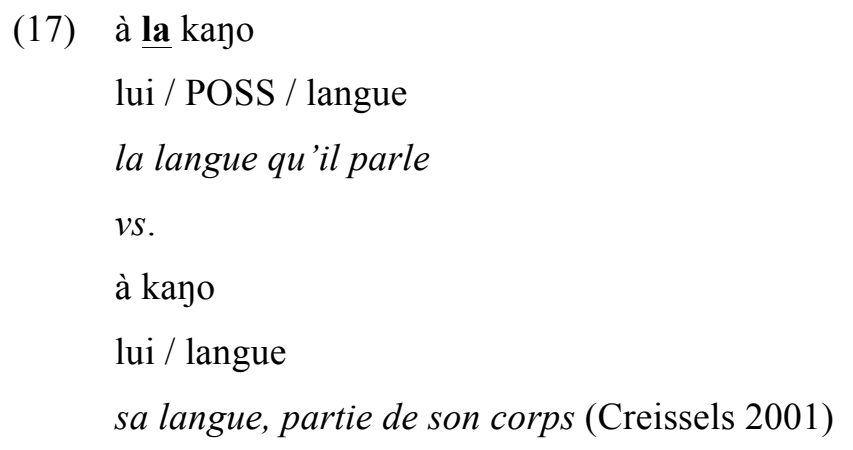

The locative meaning also appears in an equivalent derivational morpheme for nominal constituents ('lieu de', Creissels 1991:115):

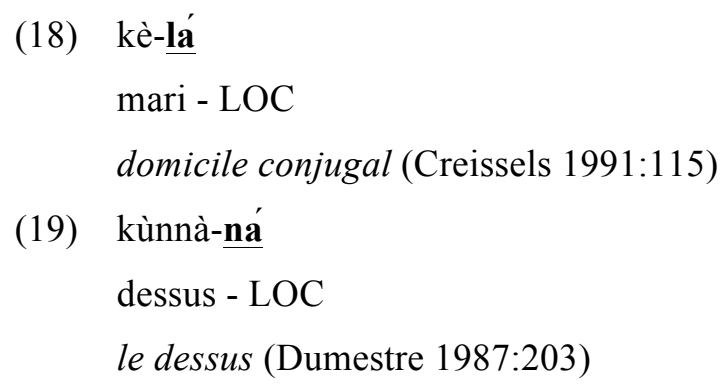

The examples from Manding all illustrate motionless locatives, that is what Tröbs (1999:365) describes as "spatial region of the reference object". In Abidjanese, these meanings run from the concrete, immediate location in the material context to abstract, discursive deictics:

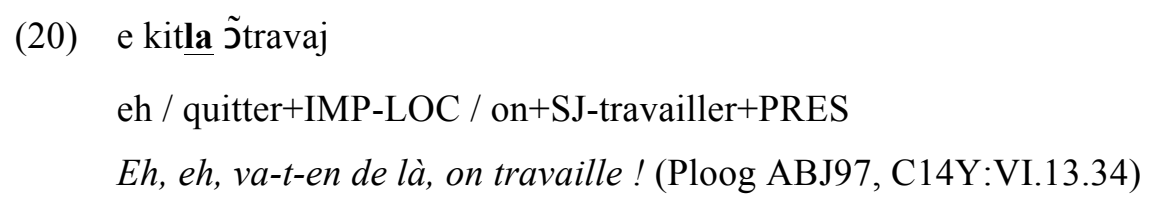

(21) Donc ma grand-mère m'a montré la vieille la, il dit de regarder la vieille la, quand la vieille là fait sa bouche (...) (Knutsen 1999)

So as in Manding, [LOC] can be used metaphorically, i.e. with temporal meaning:

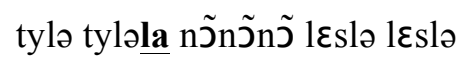


à paraître in : Journal of Language Contact, Thema series $\mathrm{n}^{\circ} 2$ : Language Contact and the Dynamics of Language : Theory and Implications, 249-273.

tuer-lui+OBJ / tuer- lui+OBJ-LOC / non (bis, ter) / laisser-lui+OBJ (bis)

Tue-le, tue-le là, non non non, laisse-le laisse-le (Ploog Abj97, C16Y:VII.08/064)

Two additional uses of the Manding postposition with temporal meaning is the verbal suffix for accomplished $[\mathrm{ACC}]$ or progressive events [PROG]:

(23) à júgu-la

lui / méchant / ACC

il s'est fâché (Dumestre1971:52)

vs.

á ká júgu

lui / COP / méchant

il est méchant (Dumestre1971:52)

(24) à bòli-la

lui / courir / ACC

il a couru (Dumestre1971:52)

(25) N nye kuma-la.

1SG / PROG / parler / PROG*

je parle (Camara 1999:37)

(26) Den tè sinöö-la

enfant / NEG / dormir / PROG*

L'enfant ne dort pas (Camara 1999:42)

The apparent contradiction between [ACC] and [PROG] of course can be attributed to different theoretic orientations of the authors or to interdialectal discrepancies; but as Creissels (1983:166) argues that LA within the (discontinued) verbal form for progressive predications is categorized as a postposition, we assume that the genuine expression of the progressive aspect would be the preverbal marker (nye/tè); the functional value of LA would be a mere 'local actualization' of the event. Sangaré (1987) agrees that the 'progressive' aspect in Dyula is not grammaticalized but merely results from referential features of the predication terms. In this order, achievement [ACC] represents the non-marked aspect, and the postposition also marks actualization in that structure.

Two additional acceptations can be considered to derive from the locative, when LA is used to mark animate oblique objects [OOB]: 
à paraître in : Journal of Language Contact, Thema series $\mathrm{n}^{\circ} 2$ : Language Contact and the Dynamics of Language : Theory and Implications, 249-273.

(27) sékù jé ádámá sว̃ wárí lá (cf. 7)

$v s$.

sékù jé wárí dí ádámá mà

Sekou / ACC / argent / donner / Adama / POST*

Sekou a donné de l'argent à Adama (Creissels 1991:366)

- And, analogous to the locative former, as a nominalization morpheme for agents $[\mathrm{AGT}]^{16}, \mathrm{a}$ former for the 'location/origin of the event' :

$$
\begin{array}{ll}
\text { (28) } & \text { sìnògò-lá } \\
& \text { dormir - AGT* } \\
& \text { dormeur (Creissels 1991:115) } \\
\text { (29) } & \text { kíní-tóbí-lá } \\
& \text { riz - cuire - AGT* } \\
& \text { cuisinière (Creissels 1991:115) }
\end{array}
$$

The formers [AGT] and [LOC] are very productive in actual Manding ${ }^{17}$.

Despite the fact that Mande speakers emphasize a distinction between the verbal and the nominal marker/former, both can be based on the very meaning of 'local actualization', referring to the etymological interpretation of Tröbs (1999).

In Abidjanese, the locative clitic has been restructured first as exclusive nominal actualization (in opposition with $\varnothing$ for generic / unspecific referents) [DEF]:

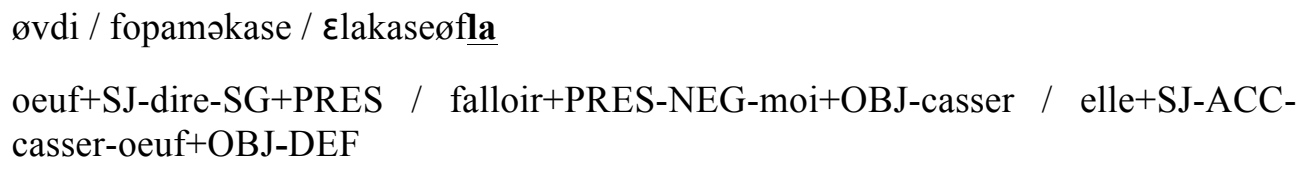
casser-oeuf+OBJ-DEF

L'oeuf dit "faut pas me casser" - elle a cassé l'oeuf en question (Ploog ABJ1997, B32Y:IV.10.45)

Preserving the general feature of actualization, LA developed the tendency to mark phrases (even whole clauses) with thematic character, within a more complex argumentation; similar observations have been made by Ludwig \& Pfänder (2003) who called this function "marqueur de connivence" and by Barberis (1987) "LA de clôture" [SPEC]:

\footnotetext{
${ }^{16}$ I.e. « qui fait l'action de », (Creissels 1991:115); « agent permanent », Dumestre (1987:224).

17 They seem to have spread over to other languages of the subregion; in fact, we observe structural convergence in this point with Ewe, a Kwa language from Ghana/Togo.
} 
à paraître in : Journal of Language Contact, Thema series $\mathrm{n}^{\circ} 2$ : Language Contact and the Dynamics of Language : Theory and Implications, 249-273.

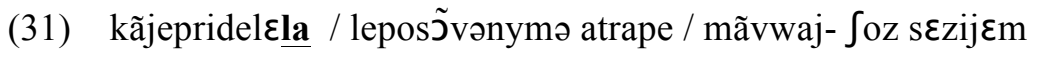

quand moi+SJ SG+PARF+prendre-delay+OBJ-SPEC / DET+PL-policiers+SJ $\mathrm{PL}+\mathrm{ACC}$-venir-moi+OBJ / attraper / moi+OBJ-PL+ACC-envoyer / chose / seizième

quand j'ai pris du diluant là les policiers sont venus m'attraper m'envoyer (chose) au XVIe commissariat (Ploog ABJ97, B30X:II.05.38)

It has to be observed that the phrase marker, when applied to nominal subjects, collides with the preposed verb former that also takes the form LA, so that the outcome is an ambiguous structure $[\mathrm{ACC}]$ :

(32) mẽnãlafamladi / wi

(a) maintenant-DEF+SG+FEM-femme-SPEC-dire / oui

Alors la femme-là dit oui

(b) maintenant-DEF+SG+FEM-femme-ACC ${ }^{18}$-dire / oui

Alors la femme lui a dit oui (Ploog ABJ97, GWX142:III.06.112)

Once more, a parallel can be established with another Manding structure, where LA can be used as a verbal formative for causative predications ('preverb', Tröbs 1999) [CAUS]:

(33) lá-wuli

CAUS - lever*

soulever (cf. wúli, se lever; Dumestre 1971:55)

(34) à bé č̌ lá-bó

lui / INACC / homme / CAUS / sortir

il fait sortir l'homme (cf. the passive construction: č̌ bé lá-bj', l'homme se fait sortir; Creissels 1991:17)

(35) sékù jé ádámá lá-bó só kJ́nj

Sekou / ACC / Adama / faire sortir / maison / dans

Sekou a fait sortir Adama de la maison (Creissels 1991:448)

vs.

sékù jé mùrú bכ’ bว̀ré kว́nว’

Sekou / ACC / couteau / sortir / sac / dans

Sekou a sorti le couteau du sac (Creissels 1991:448)

\footnotetext{
${ }^{18}$ The present $[\mathrm{ACC}]$-morpheme combines the features of object, achievement and singular.
} 
à paraître in : Journal of Language Contact, Thema series $\mathrm{n}^{\circ} 2$ : Language Contact and the Dynamics of Language : Theory and Implications, 249-273.

A small extract from Camara's Dyula learning method ${ }^{19}$ illustrates the conceptual closeness of (1.) the causative and the achievement verbal markers, and of (2.) the locative and the agentive suffix:

Les dérivatifs

Le Malinké utilise beaucoup la dérivation comme procédé de formation des noms. Par exemple : $[\ldots]$

$\mathrm{LA}=$ agent de derivation (celui qui) $[\ldots]$

fulefela $=$ joueur de flûte $[\ldots]$

1. Prefixes

LA: indique l'achèvement avec un résultat que l'on constate [...]

ka möö lakunun - réveiller quelqu'un

ka den nakasi - faire pleurer l'enfant

2. Suffixes $[\ldots]$

LA: indique les membres d'un clan

Turela - chez les Touré

On notera que l'on peut dire : Kantelaka - ressortissants du clan des Kanté.

Finally, we have to mention two additional formers for NPs that seem difficult to integrate into the dynamics, [MONEY] for accounts and [ABST] for abstract entities ${ }^{20}$ :

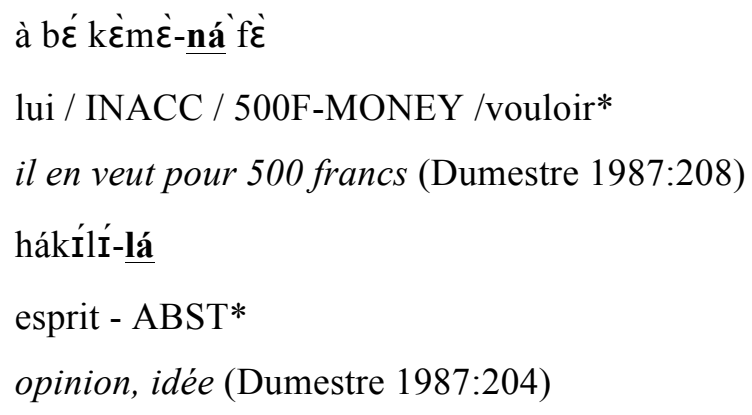

In summary, we observe:

- referential polyvalence within the central domain of actualization (from locative to specific),

- a wide range of morpho-syntactic constructions and significant structural ambiguity,

- a French-Manding referential and morphosyntactical continuum of the form.

All three characteristics seem to support the dynamics in the sense that they leave (more) space for reinterpretation by the hearer. In this sense, structural ambiguity can be associated with the creative aspect of language according to Coseriu (1981) and Oesterreicher (2003).

${ }^{19}$ See Camara (1999:26-7). It can be assumed that his more intuitive spelling intends to give an easily intelligible form with respect to western orthographic standards.

${ }^{20}$ Dumestre (1987:193) proposes to distinguish those derivational morphemes that are basically functional head ('centre de construction': [MONEY] and [AGT]) of NP's from those that can be used for a head or a modifier ([LOC] and $[\mathrm{ABST}])$, though he recognizes that there is no categorical difference between them. 
à paraître in : Journal of Language Contact, Thema series $\mathrm{n}^{\circ} 2$ : Language Contact and the Dynamics of Language : Theory and Implications, 249-273.

\subsection{Interlocutivity}

The concept of interlocutivity describes all those formal features of discourse that result directly from the duality of communication.

From the production perspective, speech is intended to reach an interlocutor. The cooperative principle (Grice 1975, see above) would predict that the speaker develops strategies to create interactional harmony, for instance, by ensuring that the hearer follows his/her purpose. Accommodation (Giles et al. 1991) and 'negotiation' (Thomason 2001) strategies can also be supposed to be based on this dynamics.

The process of developing new communicative functions of French in the Abidjanese context since its generalization (massively in phase 5 of the dynamics) required restructuring in order to cover more diversified pragmatic demands. For instance, the emergence of literary genders (oral stories as fairy tales, jokes, wordplays, etc.) required more abstract phoric strategies that explain the reinterpretation from the original 'demonstrative' LA for 'specific' purposes.

The mere routinization of frequent constructions leads to the reduction of their functional 'weight': as the verbal prefix LA is the most productive, the precise different functional components tend not to be distinguished any more. Thus, it gives room for reinterpretation.

Simultaneous to the routinization of pragmatic demands, some of the routines became discursive traditions - for instance, a high speech flow in Abidjanese indicates a good performance.

From the reception perspective, the routinization of structuring has to be interpreted in terms of perception of language constructions. Though any work about language perception seems at the very least polemic ${ }^{21}$, approaching the speaker's awareness of functional features will be decisive for the semiotization process. The vectors of such an investigation can only be sketched out here.

It will be of interest to establish to what extent the hearer is conscious of discursive traditions; this can help us to understand the configuration of different microsystems in local language architectures.

The speaker is supposed to negotiate face and to be attentive to avoid marginalization ${ }^{22}$ : As the determination of nouns by the mere LA is associated with the pidgin stage of the dynamics and stigmatizes illiterate speakers, speakers generally will prefer to produce alternative constructions (with both preposed and postposed determination paradigms) in order to show their genuine urban identity. An inverse, equivalent strategy is observed from highly educated speakers that omit more or less voluntarily the preposed article in informal interactions or with less educated interlocutorsthis strategy also supports the subcategorization of the determination by the mere LA as a quasiemblematic feature of non-standard speech.

\subsection{Linearity}

Linearity is the major substantial pragmatic demand of spoken language. The concrete constraints that result from linearity depend on the concrete planification context of a speaking task: spontaneity generally is known to produce repetitions, syntactic errors and superfluous sequences among other hesitation phenomena, that have been called 'syntactical stalling' by BlancheBenveniste (1987). Actually, it is often impossible to establish to formally distinguish a hesitation phenomenon from rhetoric strategy. That also means that in cultures with oral tradition, construction routinization is heavily influenced by the restrictions of linearity. For instance,

\footnotetext{
${ }^{21}$ Only last week I met a highly professional sociolinguist who argued (publicly) that he never adapts his speech following interactional factors ...

${ }^{22}$ As sketched out in 4.1 , the inverse dynamics has also been taken into account: following the interactional configuration, the need of expressivity can lead speaker to improve new strategies to mark distance with the common rules of the group (i.e. socioindexicality involves creativeness).
} 
à paraître in : Journal of Language Contact, Thema series $\mathrm{n}^{\circ} 2$ : Language Contact and the Dynamics of Language : Theory and Implications, 249-273.

memorization requires a very clear organization of textual coherence: repetitions are helpfulfunctional strictu sensu-rather than ungraceful.

One important constraint of linearity is word order. But as it is often unknown what kind of data underlie linguistic typology (spoken or written, clause translations, texts responding to some discursive tradition, etc.), the discussion about word order is unavailing. The fact is that the mention of a discourse topic before predicating follows a cognitive hierarchy that is more salient and therefore more accessible to illiterate speakers than grammatical rules as e.g. subject-verb sequencing. The fact that constructions like:

(39) laezon (cf. 5)

find an equivalent in Dyula:

(40) jã́ ká-dí

ici / est-bien (Creissels 1991:208)

(41) kúnũ̀ dí jára

hier a été bien (Creissels 1991:208)

must not obscure that in oral dynamics the initial position is typically destined to topical constituents. On the contrary: it reminds us that microsystems are only relatively independent since they maintain relations with contextually surrounding microsystems that will induce more dynamics.

Linearization also plays a role in the complex of prefix/suffix interpretation, which is represented in our case by LA 'boxed' between the topic and the predicative element. As a minimal consequence, we need to take into account the prosodic integration (duration, accentuation, intonational patterns) of the observable.

The tonal characteristics of LA have not clearly been outlined as yet. According to the French distinction of two paradigms, the prosodic distinction of at least an autonomous constituent and a clitic marker seems to come out ( $c f$. Ploog 2006). But Lafage had the intuition that specific prosodic patterns for the postposed LA in Abidjanese, particularly when marking a clause, can be observed: « lorsque le là est postposé à une proposition qui précède la principale, il est prononcé avec un ton haut et un durème » (Lafage 2002/2003:525). It will be useful to gather prosodic data from Dyula, especially about tonal structuring. Our information about the high/low tone is exclusively provided by the written documentation of oral data, presented by the authors proper transcription conventions. For instance, the influence of downdrift on French intonational units and accentuation can be highly relevant for the dynamics of the LA microsystem as it is often located in final position of the phrase.

\section{Discussion: the favorite form for construction paradigms}

We can synthesize the different functions of LA in Abidjanese speech in three paradigms:

- a position for locative or temporal items ('adverbs' or 'nouns') integrating an open paradigm of syntactic constituents: là/ici/lày/da/jắ/là-bas/etc;

- a phrase marker ('postpositions', 'clitics') with locative, demonstrative, or specific value, and minimally a marker of discursive actualization;

- a constituent former (derivational/flexional morphemes) with causative or achievement value, and minimally of discursive actualization. 
à paraître in : Journal of Language Contact, Thema series $\mathrm{n}^{\circ} 2$ : Language Contact and the Dynamics of Language : Theory and Implications, 249-273.

How can we then delineate the general evolution of LA in Abidjanese use? It is obvious that in both historic entities, French and Manding, the item LA has independently undergone a grammaticalization process (constituent $>$ marker $>$ former). But as it has been outlined in section 3 , the more recent evolution has taken place jointly; furthermore, the strongest dynamics is recent.

We would assume that the different elaboration constraints of LA must be coordinated in order to induce any change because the principle of structural consistency predicts that the biggest number of items will be reproduced (through co-occurrence routines) as far as they are efficient ('never change a winning team'). We have outlined that structural ambiguity can be supposed to stimulate language dynamics, since the two (ambiguous) constructions become closer to each other in the repertory of the hearer the more frequently they occur. This can be considered as an interaction between quantitative and qualitative aspects of the speech elaboration/interpretation dynamics: The metalinguistic dynamics of structuring is determined, at the same time, by the frequency and by the distinctiveness (the functionalities) of perceived constructions.

The fact is that the formal change is insignificant.

During maximal growth of the community (phase 3), the majority of the speakers were competent neither in standard French nor in Dyula. In this sense, underdetermination can be supposed to be counterproductive to consistency since it permits the reinterpretation of features. Thus a second principle would be that heterogeneous speakers' repertories support structural underdetermination (that supports dynamics). That is why contact is only indirectly responsible for dynamics. The striking fact is that the original functional characteristics are (accidently, as it seems) very close and situated in a continuum of discursive actualization of referential entities, so that there is no reason to draw a line between the French and the Manding microsystems of LA. Consequently, we will argue that the paradigms integrate into one new microsystem, that describes a complex of formal strategies for 'contextual (discursive or situational) reference'. Learners could have noticed the very frequent form LA and (re-) structured its functions gradually in a single microsystem. In fact, the two microsystems must coexist separately before coalescing to ensure the transfer of their functions into the new microsystem. In some way, equivalence strategies due to isomorphism favor consistency.

We would argue that the 'fusion' of the microsystems was effective in the eighties (phase 5), in the context of subcategorization of the various uses. How then is this coordination structuring in discourse? The brief discussions about interlocutivity and linearity show that the different pragmatic demands go together: referenciation takes place in the context of linearity and interlocutivity; interlocutivity (as a process: negotiation) is specified by linearity and referentiality; linearization necessarily takes interlocutivity and referentiality into account. Independent of the awareness of the speaker about these demands, his/her speech has to fulfill them in order to be effective.

The major aspects of the LA microsystem presented in 6.1.- the 'interlinguistic' continuum as well as the structural and referential polyvalence-explain together that it has become, in a certain way, a kind of favorite form for structuring. According to the assumption of coalescence, we would claim that language dynamics affects the integral list of functional entries through building a hierarchy of their usefulness with regard to the pragmatic demands of use; annex 1 presents the inventory of these functions.

\section{Concluding Remarks}

We discussed the emergence of discursive traditions in a contact situation by studying the characteristics of spoken data. The case of LA shows that the 'usefulness' of constructions in the grammaticization process can be evaluated by defining the strategies that allow to satisfy the pragmatic demands. The dynamics will include aspects of frequency that have not been discussed 
à paraître in : Journal of Language Contact, Thema series $\mathrm{n}^{\circ} 2$ : Language Contact and the Dynamics of Language : Theory and Implications, 249-273.

here, but that are relevant for the working out of discursive traditions. The structural processes of coalescence that took place in this dynamics remain to be explained.

However, establishing discursive traditions requires a second glance. Except from the scholastic point of view, where it would be seen as an independent inventory of rules, grammar in the sense of grammaticization is the historical sedimentation of speech features. In this sense, semiotization is an implicit, everyday process carried out by the members of a speech community during interaction. In order to make explicit how these rules work as historic facts we have to reinterpret our findings from the speech data by means of collecting meta-/epilinguistic data about the observables. And since they are the best to remember that 'clauses' appear in interactions, sociolinguists are definitely suited to be the ones who could best develop reliable methods for 'grammaticality' tests.

\section{References}

Andersen, Henning (ed.), 2001, Actualization. Linguistic Change in Progress, Amsterdam: John Benjamins.

Baker, Philip, 2003, "Quelques cas de réanalyse et de grammaticalisation dans l'évolution du créole mauricien", Kriegel, Sibylle (dir.), Grammaticalisation et réanalyse. Approche de la variation créole et française, 111-141.

Barberis, Jeanne-Marie, 1987, Deixis spatiale et interaction verbale: un emploi de «la», Cahiers de praxématique 9.

Bendor-Samuel, John (ed.), 1989, The Niger-Congo Languages, SIL / University Press of America.

Blanche-Benveniste, Claire, 1981, La complémentation verbale: valence, rection, associés, Recherches sur le français parlé 3, 57-98.

Blanche-Benveniste, Claire, 1987, Syntaxe, choix de lexique et lieux de bafouillage. DRLAV 36-37, 123-157.

Beebe, L.M. \& H. Giles, 1984, "Speech-accomodation theories: a discussion in terms of second language acquisition". International Journal of the Sociology of Language 46, 5-32.

Camara, Mamadou, 1999, Parlons malinké, Paris: L'Harmattan.

Coseriu, Eugenio, 1981, Introducción a la lingüística. Madrid: Gredos.

Creissels, Denis, 1983, Eléments de Grammaire de la Langue Mandinka, Grenoble: ELLUG.

Creissels, Denis, 1991, Description des langues négro-africaines et théorie syntaxique, Grenoble: ELLUG.

Creissels, Denis, 2001, Catégorisation et grammaticalisation. La relation génitivale en mandingue, In: Nicolaï, Robert (ed.), Leçons d'Afrique. Filiations, ruptures, et reconstitution de langues. Hommage à Gabriel Manessy. Louvain/Paris: Peeters, 433-454.

Croft, William, 1995, Autonomy and functionalist linguistics. Linguistics 71, 490-532.

Croft, William, 2003 (1990), Typology and universals, Cambridge: Cambridge University Press.

Derive, Marie-Josée, 1976, Dioula véhiculaire, dioula de Kong et dioula d'Odienné, Annales de l'Université d'Abidjan, série H tome IX/1, 55-83.

Dressler, Wolfgang \& Willi Mayerthaler \& Oswald Panagl \& Wolfgang Ullrich Wurzel, 1988, Leitmotifs in Natural Morphology, Amsterdam: John Benjamins. 
à paraître in : Journal of Language Contact, Thema series $\mathrm{n}^{\circ} 2$ : Language Contact and the Dynamics of Language : Theory and Implications, 249-273.

Dumestre, Gérard, 1971, Catégories grammaticales en Dioula de Côte d'Ivoire. Nom, verbe, adjectif, Annales de l'Université d'Abidjan, série H, tome IV/1, 51-59.

Dumestre, Gérard, 1987, Le bambara du Mali: essais de description linguistique, Sorbonne nouvelle / Institut des langues orientales: Thèse d'état (ss. la dir. de M.Houis).

Dumestre, Gérard, 2003, Grammaire fondamentale du bambara. Paris: Karthala.

Fleischman, Suzanne, 1983, From pragmatics to grammar. Diachronic reflections oncomplex pasts and futures in Romance. Lingua 60, 183-214.

Fournier, Robert, 1998, Des créolismes dans la distribution des déterminants et des complémenteurs en français québécois basilectal, In Brasseur (ed.) 1998: Français d'Amérique. Variation, créolisation, normalisation", Centre d'Etudes canadiennes de l'Université d'Avignon (CECAV), 217-228.

Giles, Howard \& Nikolas Coupland \& Justine Coupland, 1991, Accomodation theory: communication, context and consequence. In: Giles, Howard \& Justine Coupland \& Nikolas Coupland (eds.), Contexts of accomodation: Developments in applied sociolinguistics, Cambridge: CUP, 1-68.

Goffman, Erving, 1959, The Presentation of Self in Everyday Life. Doubleday: Garden City, New York $^{\mathrm{n}}$

Goffman, Erving, 1963, Stigma. Prentice-Hall: Englewood Cliffs, New Jersey.

Goldberg, Adele E., 2005, Constructions at Work. The Nature of Generalization in Language. Oxford: Oxford University Press.

Greenberg, Joseph H. (ed.), 1963a, Universals of Language. Cambridge : MIT Press.

Greenberg, Joseph H., 1963b, Languages of Africa. Bloomington : Indiana Research Center in Anthropology, Indiana University Press.

Grice, Paul H., 1975, Logic and Conversation. In: Cole, P. \& J.L. Morgan (1975), Speech Acts (Syntax and Semantics 3), New York : Academic Press, 41-58.

Harris, Alice C. \& Campbell, Lyle, 1995, Historical syntax in cross-linguistic perspective, Cambridge: Cambridge University Press.

Hattiger, Jean-Louis, 1978, Contribution à une étude des déterminants du nom en français populaire d'Abidjan, Abidjan: Cahiers ivoiriens de recherche linguistique 4, 1-20.

Hattiger, Jean-Louis, 1983, Le français populaire d'Abidjan: un cas de pidginisation, Abidjan: Publication de l'ILA 87.

Heine, Bernd \& Tania Kuteva, 2002, World Lexicon of Grammaticalization, Cambridge: Cambridge University Press.

Heine, Bernd \& Tania Kuteva, 2005, Language contact and Grammatical Change, Cambridge: Cambridge University Press (coll. Cambridge Approaches to Language contact).

Hopper, Paul J., 1979, Aspect and foregrounding in discourse. In: Givón, Talmy (ed.), Discourse and Syntax. New York: Academic Press, 213-241.

Hopper, Paul, 1987, Emergent Grammar, Berkeley Linguistics Society, vol. 13, 139-157.

Hopper, Paul J. \& Elizabeth C. Traugott, 1993, Grammaticalization, Cambridge: Cambridge University Press. 
à paraître in : Journal of Language Contact, Thema series $\mathrm{n}^{\circ} 2$ : Language Contact and the Dynamics of Language : Theory and Implications, 249-273.

Italia, Magali, 2006, Le morphème là dans les variétés mésolectales et basilectales en français du Gabon, Le français en Afrique (ROFCAN) 21, 281-290.

Jabet, Marita, 2005, Omission de l'article et du pronom sujet dans le français abidjanais, Lund: Romanska Institutionen Lunds Universitet (Etudes romanes de Lund $\mathrm{n}^{\circ} 74$, thèse de doctorat).

Jacob, Daniel, 1992, "Relative Referenzbereiche oder: Was ist Definitheit?", In: Anschütz, Susanne R. (ed.), Texte, Sätze, Wörter und Moneme. Heidelberg: Orientverlag, 301-323.

Jacob, Daniel, 2003, Niveaux de grammaticité : de la fonction primaire à l'autonomie grammaticale. Travaux 18 (La grammaticalisation. La terminologie), 59-81.

Johanson, Lars, 2005, "On copying grammatical meaning", Sprachtypologie und Unversalienforschung 58/1, 75-83.

Knutsen, Anne Moseng, 1999, "Formes et emplois verbaux en français populaire d'Abidjan (Côte d'Ivoire)". Oslo : Universitetet i Oslo, Klassisk og romansk institutt : Narcisse 18, 51-71.

Knutsen, Anne Moseng, 2002, Le statut de là en français abidjanais, Romansk Forum XV Skandinaviske romanistkongress $\mathrm{n}^{\circ} 16$ - 2002/2 (Oslo 12.-17. August 2002), 553-559.

Knutsen, Anne Moseng \& Katja Ploog, 2005, La grammaticalisation de LA en (français) abidjanais: une marque à tout faire ?, In: Kabatek, Johannes \& Claus D. Pusch \& Wolfgang Raible (eds.): Romanistische Korpuslinguistik II: Korpora und diachrone Sprachwissenschaft / Romance Corpus Linguistics II: Corpora and Diachronic Linguistics (ScriptOralia 130). Tübingen: Narr, 469-482.

Kriegel, Sibylle, 2003, Grammaticalisation et réanalyse. Approche de la variation créole et française, Paris: CNRS éditions.

Kroch, Anthony, 1989, "Reflexes of grammar in patterns of language change", Language Variation and Change 1, 199-244.

Kroch, Anthony, 2000, Syntactic change. In Baltin, Mark \& Chris Collins (eds.), Handbook of Contemporary Syntactic Theory. London: Blackwell.

Lafage, Suzanne, 1998, Le français des rues - une variété avancée du français abidjanais, Faits de Langues 11/12, 135-144.

Lafage, Suzanne, 2002/2003, Le lexique français de Côte d'Ivoire (Le français en Afrique 16/17, Revue du Réseau des Observatoires du Français contemporain en Afrique Noire), Nice: CNRS / Institut de Linguistique française (2 vol.).

Langacker, Ronald W, 1977, Syntactic Reanalysis, In: Li, Charles N. (ed.), Mechanisms of syntactic change. AustIn: University of Texas Press, 57-139.

Langacker, Ronald, 1990, Subjectification. Cognitive Linguistics 1, 5-38.

Lefèbvre, Claire (et al.), 1982, Syntaxe de l'Haïtien, Ann Arbor: Karoma Publishers.

Lehmann, Christian, 2002 (1995), Thoughts on Grammaticalization. (2nd revised edition) Munich: Lincom Europa.

Ludwig, Ralph \& Stefan Pfänder, 2003, La particule LÀ/LA en français oral et en créole caribéen: grammaticalisation et contact de langues, Kriegel, Sibylle (dir.), Grammaticalisation et réanalyse. Approche de la variation créole et française, 269-284. 
à paraître in : Journal of Language Contact, Thema series $\mathrm{n}^{\circ} 2$ : Language Contact and the Dynamics of Language : Theory and Implications, 249-273.

Lumsden, John S, 1991, La distribution des modificateurs dans le syntagme nominal haïtien, Recherches Linguistiques de Vincennes 20, 47-63.

Manessy, Gabriel, 1987, Créolisation et créolité. Etudes créoles X/2, 25-38.

Manessy, Gabriel, 1989, De la subversion des langues importées : le français en Afrique noire. In: Chaudenson (ed.), Langue, économie et développement, 133-145.

Manessy, Gabriel, 1995, Créoles, pidgins, variétés véhiculaires : procès et genèse. Paris : éditions CNRS (coll. sciences du langage).

Meillet, Antoine, 1952 (1921), Linguistique historique et linguistique générale, Paris: Honoré Champion.

Milroy, James, 2003, On the role of the speaker in language change, In: Hickey, Ramond (ed.): Motives for Language Change, Cambridge: University Press, 143-460.

Mithun, Marianne, 2007, Grammar, Contact and Time. Journal of Language Contact, Thema 1. (http://www.jlc-journal.org/), 144-164.

Myers-Scotton, Carol, 2002, Contact linguistics: Bilingual encounters and the grammatical outcome. Oxford: Oxford University Press.

Myers-Scotton, Carol, 2007, Testing the 4-M Model with Contact Data, Symposium Language Contact and the Dynamics of Language: Theory and Implications (Leipzig, Max Planck Institute for Evolutionary Anthropology, 10-13 May 2007).

Oesterreicher, Wulf, 2003, Zeit - Text - Sprache. Die Zeitlichkeit von Diskursen und der Zeitkern von Sprachregeln. In: Kablitz, Andreas \& Wulf Oesterreicher (eds.), Zeit und Text. Philosophische, kulturanthropologische, literarhistorische und linguistische Beiträge. München: Wilhel Fink Verlag.

Ploog, Katja, 2002, Une promotion pour les locatifs en abidjanais ?, Copenhague: Revue romane, $37 / 1,31-43$.

Ploog, Katja, 2006, Du continuum pragmatico-sémantique aux types prosodiques de LA en (français) abidjanais, In: Queffelec (ed.), Des inventaires lexicaux du français en Afrique à la sociolinguistique urbaine... Hommages à Suzanne Lafage (Le français en Afrique $\mathrm{n}^{\circ} 21$ ), 303-324.

Ploog, Katja, 2008 (forthcoming), Le contact de langues dans les dynamiques linguistiques. (To be published in:) Mauro A. Fernández \& Alan N. Baxter \& Jürgen Lang (eds.), Contacts linguistiques. Influences et interférences. Berlin: Mouton de Gruyter.

Rialland, Annie, 1998, Systèmes prosodiques africains : une source d'inspiration majeure pour les théories phonologiques multilinéaires. Faits de Langues 11/12, 407-428.

Sangaré, Aby, 1987, L'expression du prospectif et du progressif en dioula, Cahiers ivoiriens de recherche linguistique 21, 5-23.

Schosler, Lene, 2001, Reanalysing Structure. The Modern French Definite Article, its Predecessors and Development, Acta Linguistica Hafniensia vol 33, 2001, 91-108.

Searle, John R, 1972, Les actes de langage, Herrmann, Paris.

Tera, Kalilou, 1986, Le dioula véhiculaire de Côte d'Ivoire. Expansion et dévelopement, Cahiers ivoiriens de recherche linguistique 20, 5-34. 
à paraître in : Journal of Language Contact, Thema series $\mathrm{n}^{\circ} 2$ : Language Contact and the Dynamics of Language : Theory and Implications, 249-273.

Thomason, Sarah, 2001, Language contact: an introduction, Edinburgh: Edinburgh University Press.

Traugott, Elizabeth \& Ekkehard König, 1991, The semantics-pragmatics of grammaticalization revisited. In: Traugott, Elizabeth \& Bernd Heine (eds.), Approaches to grammaticalization. Vol.1: Focus on theoretical and methodological issues. Amsterdam: John Benjamins, 189-218.

Tröbs, Holger, 1999, Lokalisation im Maninka (West-Mande), Sprachtypologie und Universalienforschung 52/3-4, 365-379.

Valdman, Albert, 1978, Le créole: structure, statut et origine, Paris: Klincksieck.

Vincent, Diane, 1993, Les ponctuants de la langue et autres mots du discours, Québec: Nuit Blanche Editeur (Thèse de l'Université de Montréal, 1983).

Weinreich, Uriel, 1967 (1953), Languages in contact. La Haye: Mouton.

Wiesmath, Raphaële, 2003, La particule LÀ dans le parle acadien du Nouveau-Brunswick/Canada, Kriegel, Sibylle (dir.), Grammaticalisation et réanalyse. Approche de la variation créole et française, 285-302.

Winford, Donald, 2003, An Introduction to Contact Linguistics, Oxford: Blackwell Publishers.

\section{Corpora}

[DGLF BOR99]: Conversational data from young urban speakers, collected in suburbs of Bordeaux (France) in 1999 with grants from the DGLFLF (reponsible: Claude Muller, ERSSAB, Université Michel-de-Montaigne Bordeaux 3).

[Ploog ABJ97]: Narrations and conversational data from young urban speakers, collected in Abidjan (Ivory Coast) in 1997. Partially published on the CRDO website: http://crdo.risc.cnrs.fr/exist/crdo/rechercher.xq (5/5/08)

Annex 1: Construction types and values of LA

\begin{tabular}{|c|c|c|c|c|c|}
\hline Label & Construction & $\begin{array}{l}\text { Discursive } \\
\text { elaboration }\end{array}$ & Pragmatic value & Example $\left(n^{\circ}\right)$ & $\begin{array}{l}\text { Discursive } \\
\text { tradition }\end{array}$ \\
\hline LOC & $\begin{array}{l}\text { Constituent } \\
\mathrm{N}\end{array}$ & NP & SEM $+[$ locative $]+[$ static $]$ & làn, da ('place') & Manding \\
\hline LOC & $\begin{array}{l}\text { Constituent } \\
\mathrm{N}\end{array}$ & $\begin{array}{l}\text { NP / COP- } \\
\text { ATTR }\end{array}$ & $\begin{array}{l}\text { DISC }+[\text { deictic }] \\
+[\text { demonstrative }]+[\text { specific }] \\
\text { SEM }+[\text { locative }]+[\text { static }]\end{array}$ & laczon (5) & Abidjanese \\
\hline LOC & $\begin{array}{l}\text { Constituent } \\
\text { Adv }\end{array}$ & NP / SV / AP & $\begin{array}{l}\text { DISC }+[\text { deictic }] \\
+[\text { demonstrative }]+[\text { specific }] \\
\text { SEM }+[\text { locative }]+[\text { static }] \\
+[\text { temporal }]\end{array}$ & $\begin{array}{l}\text { attends }+ \\
\text { regarde je mets } \\
\text { le filet }++ \\
\text { regarde }+ \text { il est } \\
\text { là }(\text { ex. } 1)\end{array}$ & $\begin{array}{l}\text { French / } \\
\text { Abidjanese }\end{array}$ \\
\hline LOC & $\begin{array}{l}\text { Marker NP : } \\
\text { NP-LOC }\end{array}$ & $\begin{array}{l}\text { NP / TAM / } \\
\text { NP / VP / NP } \\
\text { (allomorphs: } \\
\text { ro, no, ( ) }\end{array}$ & $\begin{array}{l}\text { SEM }+[\text { locative }]+[\text { static }] \\
+[\text { temporal }]\end{array}$ & $\begin{array}{l}\text { à béfí ké dàga lá } \\
\text { (14) }\end{array}$ & Manding \\
\hline
\end{tabular}


à paraître in : Journal of Language Contact, Thema series $\mathrm{n}^{\circ} 2$ : Language Contact and the Dynamics of Language : Theory and Implications, 249-273.

\begin{tabular}{|c|c|c|c|c|c|}
\hline GEN & $\begin{array}{l}\text { Marker NP : } \\
\text { NP-GEN }\end{array}$ & NP / NP & $\begin{array}{l}\text { DISC }+[\text { definite }]+[\text { actualized }] \\
\text { SEM }+[\text { locative }]+[\text { static }] \\
\text { SYN }+[\text { instrumental }] \\
+[\text { participant }]\end{array}$ & à la kano (17) & Manding \\
\hline $\mathrm{OOB}$ & $\begin{array}{l}\text { Marker NP : } \\
\text { NP-OOB }\end{array}$ & $\begin{array}{l}\text { NP / TAM / } \\
\text { NP / VP / NP }\end{array}$ & $\begin{array}{l}\text { SYN }+ \text { [instrumental] } \\
+ \text { [participant }] \\
\text { DISC ?[achieved] }+ \text { [actualized] }\end{array}$ & $\begin{array}{l}\text { Sékù jé ádámá } \\
\text { sग̃ wárí lá }(7, \\
27)\end{array}$ & Manding \\
\hline$A C C$ & $\begin{array}{l}\text { Marker VP : } \\
\text { VP-ACC }\end{array}$ & NP / (Ø) / VP & $\begin{array}{l}\text { SEM ?[locative] } \\
\text { DISC }+[\text { temporal] }+ \text { [achieved] } \\
+ \text { [actualized] }\end{array}$ & à bòli-la (24) & Manding \\
\hline PROG & $\begin{array}{l}\text { Marker VP } \\
\text { VP-PROG }\end{array}$ & $\begin{array}{l}\text { NP / TAM / } \\
\text { VP }\end{array}$ & $\begin{array}{l}\text { SEM ?[locative] } \\
\text { DISC +[temporal] -[achieved] } \\
+ \text { [actualized] }\end{array}$ & $\begin{array}{l}\text { n nye kuma-la } \\
(25)\end{array}$ & Manding \\
\hline DEF & $\begin{array}{l}\text { Marker NP : } \\
\text { NP-DEF }\end{array}$ & $\begin{array}{l}\text { NP / TAM / } \\
\text { VP / NP }\end{array}$ & $\begin{array}{l}\text { DISC }+[\text { deictic }] \\
+[\text { demonstrative }]+[\text { specific }] \\
+[\text { definite }]\end{array}$ & Elakaseøfla (30) & Abidjanese \\
\hline DEM & $\begin{array}{l}\text { Marker NP : } \\
\text { NP-DEM }\end{array}$ & $\begin{array}{l}\mathrm{C} / \mathrm{NP} / \mathrm{VP} / \\
\mathrm{NP}\end{array}$ & $\begin{array}{l}\text { DISC }+[\text { deictic }] \\
+[\text { demonstrative }]+[\text { specific }]\end{array}$ & $\begin{array}{l}\text { et pourquoi ça a } \\
\text { ces couleurs-là } \\
\text { (3) }\end{array}$ & French \\
\hline SPEC & $\begin{array}{l}\text { Marker XP } \\
\text { XP-SPEC }\end{array}$ & $\mathrm{XP} / \mathrm{C}$ & DISC $+[$ specific $]+[$ actualized $]$ & 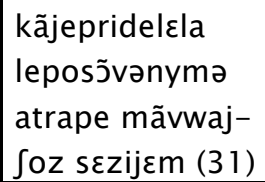 & Abidjanese \\
\hline SPEC & $\begin{array}{l}\text { Marker NP : } \\
\text { NP-SPEC } \\
\end{array}$ & NP / VP / NP & $\begin{array}{l}\begin{array}{l}\text { DISC }+[\text { specific }]+[\text { definite }] \\
+ \text { [actualized] }\end{array} \\
\end{array}$ & $\begin{array}{l}\text { mẽnãlafamladi } \\
\text { wi (32a) } \\
\end{array}$ & $\begin{array}{l}\text { Abidjanese } \\
\text { / French } \\
\end{array}$ \\
\hline ACC & $\begin{array}{l}\text { Former } V< \\
\text { ACC-V }\end{array}$ & NP / VP / NP & $\begin{array}{l}\text { SYN + [participant] } \\
\text { DISC +[achieved] +[temporal] } \\
+ \text { [actualized] }\end{array}$ & $\begin{array}{l}\text { mẽnãlafamladi } \\
\text { wi (32b) }\end{array}$ & Abidjanese \\
\hline CAUS & $\begin{array}{l}\text { Former } \mathrm{V}< \\
\text { CAUS-V }\end{array}$ & $\begin{array}{l}\text { NP / TAM / } \\
\text { NP / VP } \\
\text { (allomorphs: } \\
\text { ro, no, l ()) } \\
\end{array}$ & $\begin{array}{l}\text { SYN }+ \text { [instrumental] } \\
+ \text { [participant }]\end{array}$ & $\begin{array}{l}\text { à bé cč lá-bj́ } \\
(34)\end{array}$ & Manding \\
\hline AGT & $\begin{array}{l}\text { Former } \mathrm{N}< \\
\mathrm{V}-\mathrm{LOCC}\end{array}$ & & $\begin{array}{l}\text { SEM }+[\text { locative }] \pm[\text { static }] \\
\text { SYN }+ \text { [instrumental }] \\
+[\text { participant }]\end{array}$ & sìnògò-lá (28) & Manding \\
\hline LOC & $\begin{array}{l}\text { Former } \mathrm{N}< \\
\mathrm{N}-\text { LOC }\end{array}$ & & $\begin{array}{l}\text { SEM }+[\text { locative }]+[\text { static }] \\
\text { SYN } \\
+[\text { instrumental }]+[\text { participant }]\end{array}$ & kè-lá (18) & Manding \\
\hline MONEY & $\begin{array}{l}\text { Former } \mathrm{N}< \\
\mathrm{N}-\mathrm{MONEY}\end{array}$ & $\begin{array}{l}\text { NP / TAM / } \\
\text { NP / VP }\end{array}$ & SEM + [sum $]$ & $\begin{array}{l}\text { à bé kèmè-nâ fè } \\
(36) \\
\text { il en veut pour } \\
500 \text { francs }\end{array}$ & Manding \\
\hline$A B S T$ & $\begin{array}{l}\text { Former } \mathrm{N}< \\
\mathrm{N}-\mathrm{ABST}\end{array}$ & & $\begin{array}{l}\text { SEM +[locative] }+ \text { [static] } \\
\text { ?[sum] ?[actualized] }\end{array}$ & $\begin{array}{l}\text { hákílí-lá (37) } \\
\text { opinion, idée }\end{array}$ & Manding \\
\hline
\end{tabular}


version préliminaire! ne pas citer sans l'accord de l'auteure!

à paraître in : Journal of Language Contact, Thema series $\mathrm{n}^{\circ} 2$ : Language Contact and the Dynamics of Language : Theory and Implications, 249-273. 